Article

\title{
Enzymatic Synthesis of $N$-Acetyllactosamine (LacNAc) Type 1 Oligomers and Characterization as Multivalent Galectin Ligands
}

\author{
Thomas Fischöder ${ }^{\dagger}$, Dominic Laaf ${ }^{\dagger}$, Carina Dey and Lothar Elling * \\ Laboratory for Biomaterials, Institute for Biotechnology and Helmholtz-Institute for Biomedical Engineering, \\ RWTH Aachen University, Pauwelsstraße 20, 52074 Aachen, Germany; t.fischoeder@biotec.rwth-aachen.de (T.F.); \\ d.laaf@biotec.rwth-aachen.de (D.L.); c.dey@biotec.rwth-aachen.de (C.D.) \\ * Correspondence: 1.elling@biotec.rwth-aachen.de; Tel.: +49-241-80-28350; Fax: +49-241-80-22387 \\ t These authors contributed equally to this work.
}

Received: 14 June 2017; Accepted: 8 August 2017; Published: 10 August 2017

\begin{abstract}
Repeats of the disaccharide unit $N$-acetyllactosamine (LacNAc) occur as type 1 (Gal $\beta 1$, 3GlcNAc) and type 2 (Gal $\beta 1,4 \mathrm{GlcNAc})$ glycosylation motifs on glycoproteins and glycolipids. The LacNAc motif acts as binding ligand for lectins and is involved in many biological recognition events. To the best of our knowledge, we present, for the first time, the synthesis of LacNAc type 1 oligomers using recombinant $\beta 1$,3-galactosyltransferase from Escherichia coli and $\beta 1,3-N$-acetylglucosaminyltranferase from Helicobacter pylori. Tetrasaccharide glycans presenting LacNAc type 1 repeats or LacNAc type 1 at the reducing or non-reducing end, respectively, were conjugated to bovine serum albumin as a protein scaffold by squarate linker chemistry. The resulting multivalent LacNAc type 1 presenting neo-glycoproteins were further studied for specific binding of the tumor-associated human galectin 3 (Gal-3) and its truncated counterpart Gal-3 $3 \Delta$ in an enzyme-linked lectin assay (ELLA). We observed a significantly increased affinity of Gal-3 $\Delta$ towards the multivalent neo-glycoprotein presenting LacNAc type 1 repeating units. This is the first evidence for differences in glycan selectivity of Gal-3 $\Delta$ and Gal-3 and may be further utilized for tracing Gal-3 $\Delta$ during tumor progression and therapy.
\end{abstract}

Keywords: neo-glycoproteins; biocatalysis; LacNAc type 1; chemo-enzymatic synthesis; one-pot; sequential; glycosyltransferase; galectin-3; multivalency

\section{Introduction}

The $N$-acetyllactosamine type 1 (LacNAc type 1, Gal $\beta 1,3 G l c N A c$ ) is a well-known precursor of several important blood group epitopes, such as Lewis A, Lewis B, or sialyl Lewis A [1], which are involved in many biological processes, e.g., fertilization [2] and pathogen adhesion [3]. Furthermore, LacNAc type 1 moieties, as well as Lewis type epitopes also occur in human milk [4-6]. The LacNAc type 1 glycosylation motif itself, as part of Lewis epitope structures [7] or in repetitive sequences [8,9], has been frequently found in gastrointestinal tissues [8,10-13], lung [14] or urothelium [15]. LacNAc type 1 containing glycans play also an important role in tumor metastasis [7] and are, therefore, considered as tumor markers [13]. Repetitive sequences, i.e., dimeric LacNAc type 1 structures (di-LacNAc type 1) were identified on lactosylceramides from colonic adenocarcinoma and found in colon cancer cell lines [8,9]. We conclude that there is a rising need for the synthesis of glycoconjugates containing LacNAc type 1 repeats to gain novel insights into the interaction of carbohydrates and carbohydrate binding proteins, known as lectins. Recently, we reported on the synthesis of LacNAc type 1 oligomers consisting of up to four repetitive LacNAc units by combining a glycosyltransferase and an engineered glycosynthase [16]. However, the synthesis required the chemically synthesized 
$\alpha$-galactopyranosyl fluoride ( $\alpha \mathrm{GalF}$ ) as specific donor substrate, which is prone to hydrolysis. An alternative synthesis approach is the use of a novel $\beta 1,3$-galactosyltransferase from E. coli O55:H7, which belongs to the Leloir-glycosyltransferase family 2 (GT2, EC 2.4.1.-) and utilizes uridine $5^{\prime}$-diphosphate (UDP-) $\alpha$-D-galactose (UDP-Gal) as glycosyl donor (termed $\mathrm{WbgO}$ in reference [17]). The availability of UDP-Gal and other nucleotide sugars was significantly improved by optimized in vitro syntheses during the last years $[18,19]$.

Galectins are lectins which preferably bind $\beta$-galactoside glycan structures. Due to their dimeric or multimeric character, galectins mediate cellular communication events by glycan crosslinking [20-25]. In this way, galectins trigger immune responses and cancer progression [26-32]. Among the fifteen human galectins, chimera-type galectin 3 (Gal-3) has gained special attention. Gal-3 is upregulated in tumor cells and promotes, as secreted lectin, tumor progression and angiogenesis by receptor clustering [33] and reduction of T-cell functionality [34]. Gal-3 is, therefore, considered as druggable target for anti-cancer therapy $[35,36]$. Interestingly, Gal-3 is cleaved by matrix-metalloproteinases (MMPs) during tumor progression resulting in a Gal-3 variant, which lacks $N$-terminal amino acid residues 1-62 (Gal-3 $\Delta$ ) [37,38]. Through the partial loss of certain collagen-like domains, the self-association capability is hypothesized to be affected $[38,39]$. In cancer therapy Gal-3 $\Delta$ shows synergistic effects with existing anti-tumor drugs and can be used as adjuvant for anti-cancer therapy. Furthermore, Gal-3 $\Delta$ is suspected to have a higher ligand affinity that may result in shielding carbohydrate ligands and thus acting as negative inhibitor of Gal-3 [40-42]. However, multivalent glycan binding specificity studies of Gal-3 $\Delta$ have not been investigated so far.

We here report, to the best of our knowledge, for the first time the synthesis of poly-LacNAc type 1 oligomers using two recombinant Leloir-glycosyltransferases in a one-pot and a sequential synthesis approach. The in-house produced nucleotide sugars UDP-Gal and uridine 5'-diphosphate $\mathrm{N}$-acetylglucosamine (UDP-GlcNAc) were provided for an economic synthesis. Selected glycans were further derivatized by a squarate linker for subsequent chemical conjugation to bovine serum albumin. The novel multivalent neo-glycoproteins carrying LacNAc type 1 (Gal $\beta 1,3 \mathrm{GlcNAc})$, LacNAc type 2 (Gal $\beta 1,4 \mathrm{GlcNAc}$ ) and hybrid tetrasaccharides were tested for binding of Gal-3 and Gal-3 $\Delta$. Interestingly, we gained novel insights into the binding properties and selectivity of Gal-3 $\Delta$ owing to the neo-glycoproteins, which have been loaded solely with LacNAc type 1 glycans.

\section{Results and Discussion}

\subsection{Glycan Synthesis}

The aim of the presented work was the synthesis of LacNAc type 1 oligomers by combination of a recombinant $\beta 1$,3-galactosyltransferase from $E$. coli O55:H7 ( $\beta 3 \mathrm{GalT}$ ) and a $\beta 1,3-\mathrm{N}$ acetylglucosaminyltransferase from Helicobacter pylori ( $\beta 3 \mathrm{GlcNAcT}$ ). The bacterial $\beta 3 \mathrm{GalT}$ [17] was recombinantly expressed in E. coli as previously described for other glycosyltransferases $[43,44]$. The $\mathrm{His}_{6}$-tagged enzyme was purified and thoroughly characterized with regard to its $\mathrm{pH}$ optimum and requirement for divalent cations (Supporting Information Figure S1). Optimum reaction conditions were found with $100 \mathrm{mM}$ HEPES ( $\mathrm{pH}$ 7.5) in the presence of $5 \mathrm{mM} \mathrm{Mg}^{2+}$ which correspond to those of the bacterial $\beta 3$ GlcNAcT $[45,46]$ previously utilized for one-pot synthesis of LacNAc type 2 oligomers [47]. Accordingly, we combined $\beta 3$ GalT and $\beta 3$ GlcNAcT for LacNAc type 1 oligomer synthesis either in sequential (Scheme 1) or one-pot mode (Scheme 2). The utilized UDP-sugar donors were produced as described previously $[18,19]$. Both syntheses were started from the chemically derivatized $N$-acetylglucosamine acceptor (GlcNAc-linker-tBoc, 1) together with 1.5-fold (sequential) or two-fold (one-pot) excess of UDP-Gal and UDP-GlcNAc, respectively. Alkaline phosphatase (AP) was added in order to remove UDP as inhibitory byproduct from the reaction. 
$\mathrm{R}=\mathrm{H}_{\mathrm{S}}^{\mathrm{H}} \prod_{\mathrm{H}}^{\mathrm{H}} \overbrace{\mathrm{H}}^{\mathrm{O}}$

i: $\beta 3$ GalT, UDP-Gal, alkaline phosphatase (AP)

ii: $\beta 3 G \mathrm{c} N A c T$, UDP-GIcNAc, AP
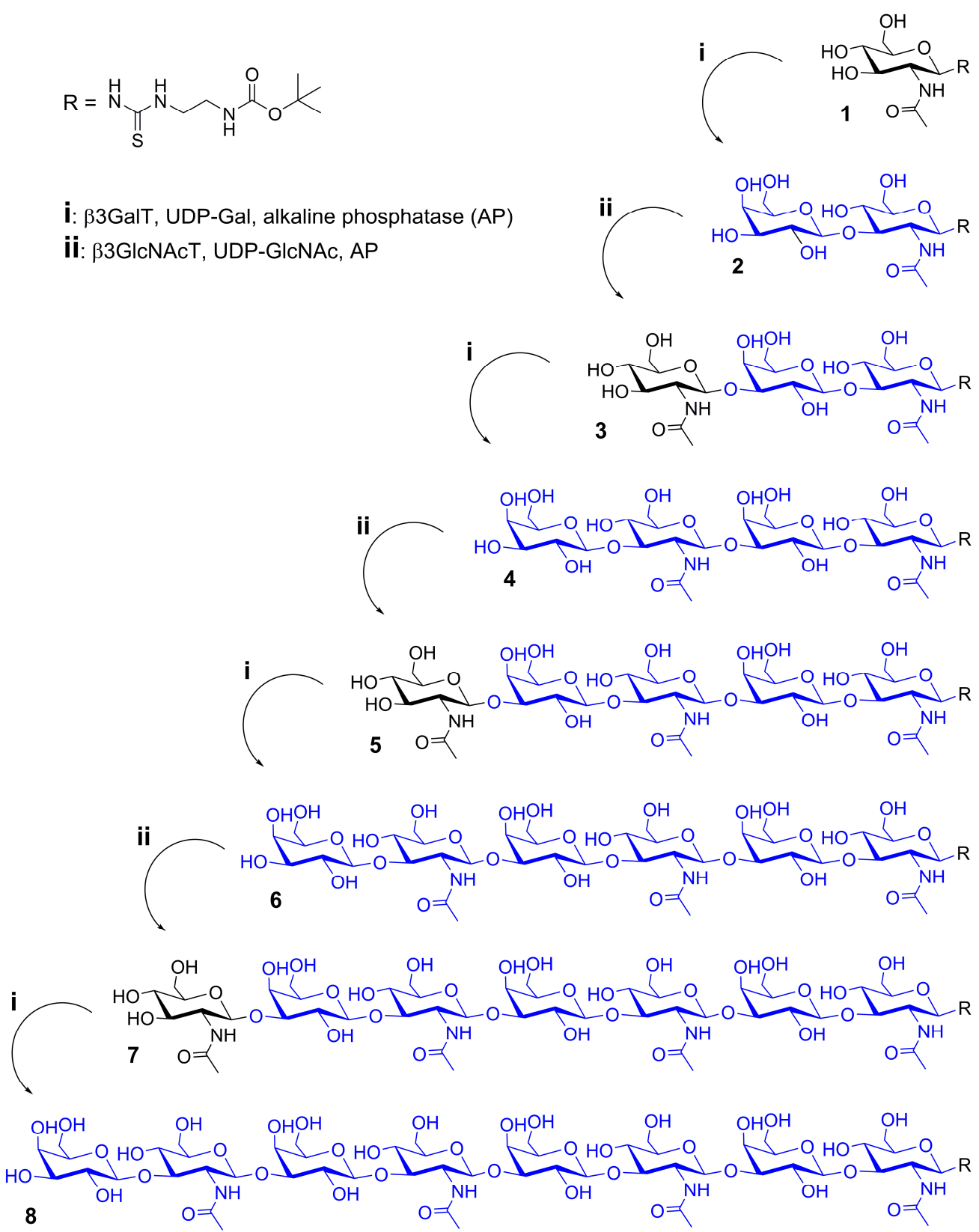

Scheme 1. Sequential synthesis of LacNAc type 1 glycan oligomers 2-8.

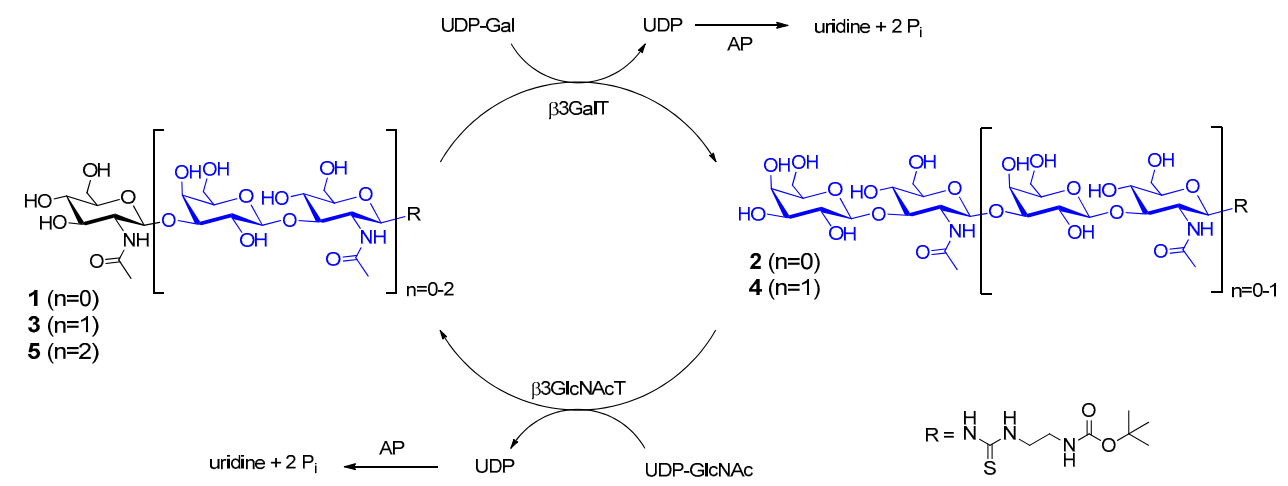

Scheme 2. One-pot synthesis of LacNAc type 1 glycan oligomers $\mathbf{2}-\mathbf{5}$. 
In the sequential mode (Scheme 1), glycan oligomers up to the pentasaccharide (2-5) were obtained in high yields with complete acceptor substrate conversion (Table 1). The hexasaccharide (6) and octasaccharide (8) could only be synthesized in low amounts, despite an additional feed of enzymes ( $\beta 3$ GalT, AP) and donor (UDP-Gal). Obviously, $\beta 3$ GalT has a low activity towards higher LacNAc type I oligomeric acceptor substrates $(5,7)$. In contrast, substrate conversion by $\beta 3$ GlcNAcT could be verified to be completed for each galactose-terminated acceptor (Table 1). The LacNAc type 1 oligomers were isolated by solid-phase extraction. The tetrasaccharide 4 consisting of two LacNAc type 1 repeats was obtained with an overall yield of $95 \%$ and utilized for the synthesis of neo-glycoproteins (Section 2.2). The integrity of LacNAc type 1 containing compounds 2-8 was confirmed by HPLC-ESI-MS (Table 1, Supporting Information Figure MS2-8). Additionally, we verified the Gal $\beta 1,3$-linkage of compound 2 by treatment with specific $\beta 1,3$-galactosidase (BgaC) [48,49] (Supporting Information Figure S12).

Table 1. Sequential synthesis of glycan oligomers 2-8 and their mass spectrometry analysis.

\begin{tabular}{cccccc}
\hline Compound & $\begin{array}{c}\text { Amount } \\
(\mu \mathbf{m o l})\end{array}$ & $\begin{array}{c}\text { Stepwise Enzymatic } \\
\text { Conversion (\%) }\end{array}$ & $\begin{array}{c}\text { Stepwise Molar } \\
\text { Yield (\%) }\end{array}$ & $\begin{array}{c}\text { Calculated } \\
\mathbf{m} / \mathbf{z}\end{array}$ & $\begin{array}{c}\text { Observed } \\
\mathbf{m} / \mathbf{z}\end{array}$ \\
\hline $\mathbf{2}$ & 9.97 & 100.0 & 98.3 & $583.2^{\mathrm{a}}$ & $583.1^{\mathrm{a}}$ \\
$\mathbf{3}$ & 9.82 & 100.0 & 98.5 & $786.3^{\mathrm{a}}$ & $786.1^{\mathrm{a}}$ \\
$\mathbf{4}$ & 9.61 & 100.0 & 97.9 & $948.4^{\mathrm{a}}$ & $948.2^{\mathrm{a}}$ \\
$\mathbf{5}$ & 9.10 & 100.0 & 94.7 & $575.3^{\mathrm{b}}$ & $575.3^{\mathrm{b}}$ \\
$\mathbf{6}$ & 2.29 & 25.2 & 24.2 & $656.3^{\mathrm{b}}$ & $656.5^{\mathrm{b}}$ \\
$\mathbf{7}$ & 2.22 & 100.0 & 96.8 & $757.8^{\mathrm{b}}$ & $758.0^{\mathrm{b}}$ \\
$\mathbf{8}$ & 0.43 & 20.9 & $838.8^{\mathrm{b}}$ & $839.1^{\mathrm{b}}$ \\
\hline \multicolumn{7}{c}{}
\end{tabular}

In our previous investigations, the one-pot combination of $\beta 3$ GlcNAcT and human $\beta 1$,4-galactosyltransferase ( $\beta 4 \mathrm{GalT}$ ) has been successfully established in order to generate LacNAc type 2 glycan oligomers with a high number of LacNAc repeats [47]. In this regard, we investigated one-pot (Scheme 2 ) reactions at varying enzyme activity ratios of $\beta 3 \mathrm{GalT}$ and $\beta 3 \mathrm{GlcNAcT}$. The reaction mixtures contained acceptor 1 ( $5 \mathrm{mM}$ ), alkaline phosphatase (AP, $10 \mathrm{U}$ ) and $10 \mathrm{mM}$ (two-fold excess) of UDP-Gal and UDP-GlcNAc, respectively. The product distribution was analyzed by HPLC after 24, 48 , and $72 \mathrm{~h}$ reaction time. Different enzyme activity ratios of $\beta 3 \mathrm{GalT}$ and $\beta 3 \mathrm{GlcNAcT}$ led to distinct product distributions (Figure $1 \mathrm{a}-\mathrm{c}$ ). Complete conversion of acceptor $\mathbf{1}$ was reached at an enzyme activity ratio of 5:1 ( $\beta 3$ GalT/ $\beta 3$ GlcNAcT) (Figure $1 b$ ) with the disaccharide 2 as main product and $14 \%$ yield for tetrasaccharide 4 after $72 \mathrm{~h}$. Higher amounts of compound 4 were not obtained (Figure 1a,c). However, compound 3 was formed as main product (after $72 \mathrm{~h}$ ) when $\beta 3$ GlcNAcT was in five-fold excess (Figure 1c). In comparison to the one-pot synthesis using an engineered glycosynthase and $\beta 3$ GlcNAcT [16] the combination of both glycosyltransferases in one-pot synthesis is limited towards the synthesis of the disaccharide and trisaccharide products.

In conclusion, the sequential synthesis approach using $\beta 3 \mathrm{GalT}$ and $\beta 3 \mathrm{GlcNAcT}$ results in the effective synthesis of LacNAc type 1 oligomers. In contrast to our previous results with $\beta 4 \mathrm{GalT}$ and $\beta 3$ GlcNAcT [47] synthesis of higher glycan oligomers was not feasible by one-pot synthesis using $\beta 3 \mathrm{GalT}$ and $\beta 3 \mathrm{GlcNAcT}$.

In addition to tetrasaccharide 4 with a di-LacNAc type 1 structure, we further investigated the synthesis of hybrid oligomers presenting LacNAc type 1 and type 2 motifs at the reducing and non-reducing end of the respective tetrasaccharides (9 and 11), depicted in Scheme 3. For this purpose, the trisaccharide 3 was converted by human $\beta 4$ GalT $[44,47]$ to yield compound 9 with terminal LacNAc type 2 (Gal $\beta 1,4 \mathrm{GlcNAc}$ ) motif (Scheme 3). The reaction was completed after $24 \mathrm{~h}$ and compound 9 was isolated by solid-phase extraction. Furthermore, trisaccharide $\mathbf{1 0}$ was synthesized as previously described [50] and used as an acceptor for $\beta 3 \mathrm{GalT}$ in order to generate terminal LacNAc type 1 glycosylation motif (tetrasaccharide 11). The reaction was performed according to the sequential reaction mode and was completed after $72 \mathrm{~h}$. The integrity of hybrid oligomers $\mathbf{9}$ and $\mathbf{1 1}$ was verified by HPLC-ESI-MS (Table 2, Supporting Information Figure MS9 and MS10). 


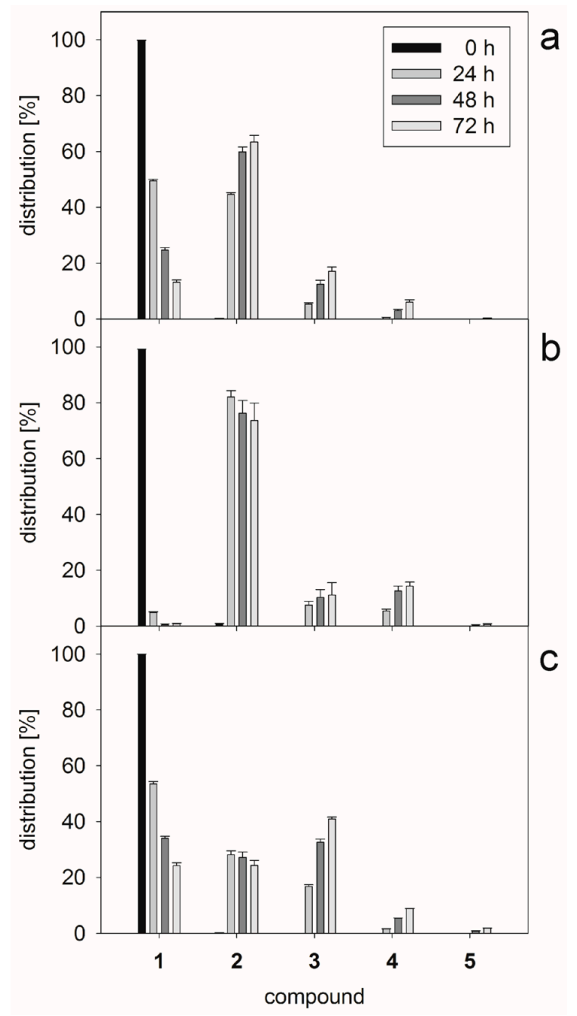

Figure 1. Relative product distribution of LacNAc type 1 glycans 1-5 from the respective one-pot syntheses after 24, 48, and $72 \mathrm{~h}$. Different enzyme activity ratios ( $\beta 3$ GalT/ $\beta 3$ GlcNAcT) of 1:1 (a); 5:1 (b); and 1:5 (c) were adjusted. All reactions contained acceptor 1 ( $5 \mathrm{mM})$, while the concentrations for UDP-Gal and UDP-GlcNAc were $10 \mathrm{mM}$. Samples were analyzed by HPLC and assigned using synthesized standards verified by HPLC-MS.

\section{a}

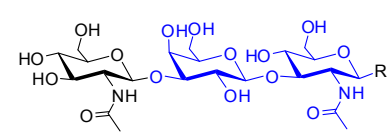

3

b

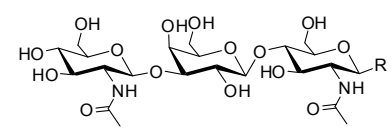

10

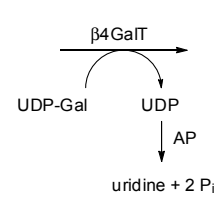

$\downarrow A P$$$
\text { (n) }
$$

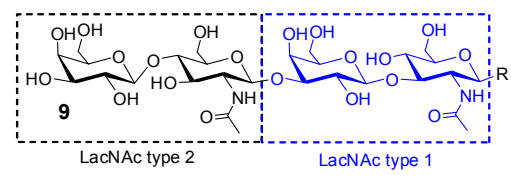

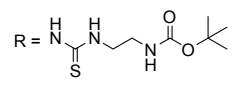
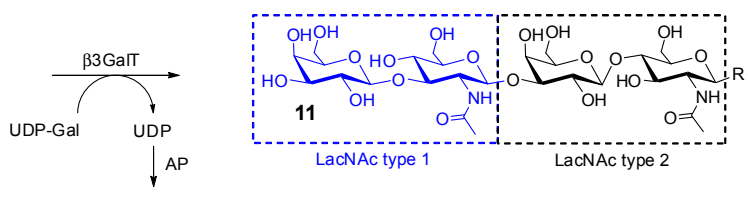

uridine $+2 \mathrm{P}_{\mathrm{i}}$

Scheme 3. Synthesis of hybrid LacNAc oligomer $\mathbf{9}(\mathbf{a})$ and $\mathbf{1 1}$ (b).

Table 2. Synthesis and MS analysis of LacNAc type 1/2 hybrid oligomers 9 and $\mathbf{1 1}$.

\begin{tabular}{cccccc}
\hline Compound & $\begin{array}{c}\text { Amount } \\
(\mu \mathrm{mol})\end{array}$ & $\begin{array}{c}\text { Stepwise Enzymatic } \\
\text { Conversion (\%) }\end{array}$ & $\begin{array}{c}\text { Stepwise Molar } \\
\text { Yield (\%) }\end{array}$ & $\begin{array}{c}\text { Calculated } \\
\mathbf{m} / \mathbf{z}\end{array}$ & $\begin{array}{c}\text { Observed } \\
\mathrm{m} / \mathbf{z}\end{array}$ \\
\hline $\mathbf{9}$ & 4.0 & 100 & 95.9 & $948.4^{\mathrm{a}}$ & $948.3^{\mathrm{a}}$ \\
$\mathbf{1 1}$ & 4.0 & 100 & 97.5 & $948.4^{\mathrm{a}}$ & $948.5^{\mathrm{a}}$ \\
\hline
\end{tabular}

${ }^{\mathrm{a}}[\mathrm{M}-\mathrm{H}]^{-}$ 


\subsection{Neo-Glycoprotein Synthesis}

Since single carbohydrate-lectin interactions are generally weak, multivalent glycan presentation is essential to trigger multiple glycan-lectin interactions owing to the cluster glycoside effect [51-53]. In addition to other platform technologies for multivalent ligand presentation, neo-glycoproteins have been synthesized by chemical coupling strategy using squarate linker chemistry [50,54-56]. Multivalent neo-glycoproteins presenting di-LacNAc type 2 tetrasaccharides have been verified as ligands for Gal-3 in previous studies [50]. The herein-synthesized LacNAc type 1-containing tetrasaccharides extend our glycan library and were further used for neo-glycoprotein synthesis.

In this regard, the tetrasaccharides $\mathbf{4}, \mathbf{9}$, and $\mathbf{1 1}$ were chemically conjugated to bovine serum albumin (BSA) to achieve a multivalent ligand presentation on a protein scaffold. Diethyl squarate (3,4-diethoxy-3-cyclobutene-1,2-dione, $\mathrm{Et}_{2} \mathrm{SQ}$ ), a homobifunctional linker, was used for the conjugation of the glycans to the amine providing lysine side chains of BSA as described previously [50]. Deprotection of the $t \mathrm{Boc}$ linker and subsequent amidation of compounds 4, 9, and 11 with $\mathrm{Et}_{2} \mathrm{SQ}$ resulted in the corresponding squarate monoamide esters 12-14 in high yields (67-88\%) after isolation by preparative HPLC (Scheme 4). The purity of isolated compounds 12-14 was confirmed by HPLC-ESI-MS (Supporting Information Table S1, Figure MS11-13). In a second step, lysine residues of BSA were reacted with squarate monoamide esters 12-14 under slightly alkaline conditions (Scheme 4). The ratio of reactants (compounds $\mathbf{1 2 - 1 4}$ to lysine residues) was adjusted to 0.375 . The reaction mixtures were incubated for seven days with gentle shaking at $23^{\circ} \mathrm{C}$.
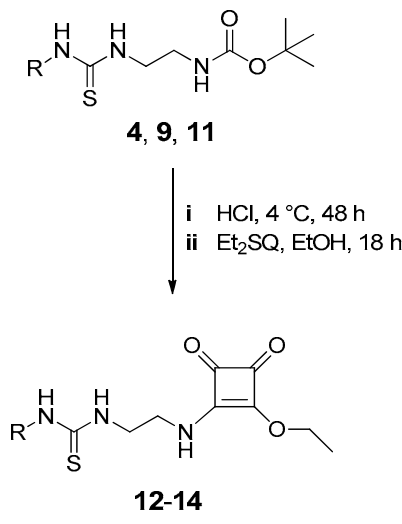

iii $\mathrm{BSA}, \mathrm{pH} 9,7$ days<smiles>[R]NC(=S)NCCNc1c(NCCCCCCCC)c(=O)c1=O</smiles>

15-17

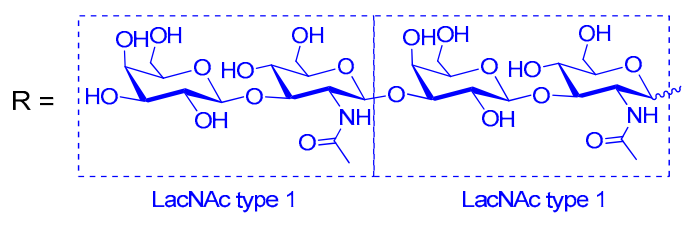

4, 12, 15

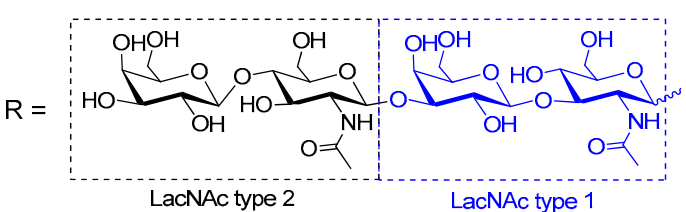

$9,13,16$

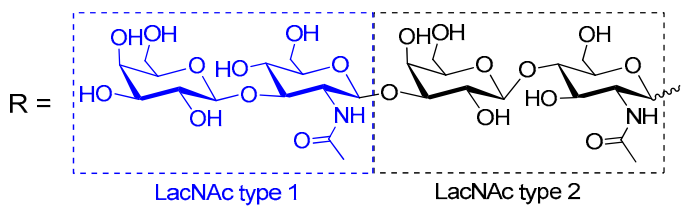

$11,14,17$

Scheme 4. Synthesis of multivalent BSA neo-glycoproteins $\mathbf{1 5 - 1 7}$ by squarate linker chemistry.

The resulting BSA neo-glycoproteins 15-17 were analyzed by sodium dodecyl sulfate gel electrophoresis (SDS-PAGE) and the 2,4,6-trinitrobenzene sulfonic acid (TNBSA) assay, as described previously [50]. SDS-PAGE analysis (Figure 2) revealed higher molecular masses of the smearing protein bands typically found for glycoproteins. Shifts towards higher molecular masses were $13.2 \mathrm{kDa}$ on average. The TNBSA assay determines the number of non-modified lysine residues, from which the number of conjugated glycans can be calculated. BSA ( $60 \mathrm{~mol}$ lysine residues per mol protein) served as a reference. We determined glycan modification densities of $16.6 \mathrm{~mol}$ (15), $16.5 \mathrm{~mol}$ (16), and $16.3 \mathrm{~mol}$ 
(17) glycans per mol BSA, respectively. The total coupling efficiency, which is the amount of reacted monoamide esters 12-14, ranged between 72\% and 74\% (Table 3). During the second coupling reaction, ethanol was the leaving group, which corresponds to a loss of $46 \mathrm{~g} / \mathrm{mol}$ for each attached glycan derivative. Given the molecular mass of squarate monoamide esters 12-14 (973 g/mol) and loss of an ethanol during reaction, the molecular mass is expected to be increased by 927 Dalton (Da) per amidated lysine residue. The calculated molecular masses (from TNBSA assay) of neo-glycoproteins 15-17 are listed in Table 3 and are in accordance with those from SDS-PAGE.

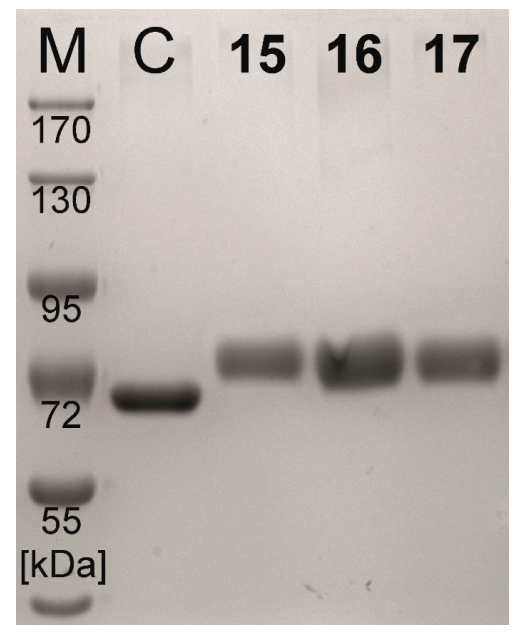

Figure 2. SDS-PAGE analysis of BSA neo-glycoproteins 15-17 and non-modified BSA as a control (C); M, PageRuler Prestained Protein Ladder (ThermoFisher Scientific, Darmstadt, Germany).

Table 3. Synthesis and analysis of BSA neo-glycoproteins 15-17.

\begin{tabular}{ccccc}
\hline Compound & $\begin{array}{c}\text { Coupling } \\
\text { Efficiency (\%) }\end{array}$ & $\begin{array}{c}\text { Conjugated Glycans } \\
\text { (TNBSA Assay) } \\
\text { (mol/mol BSA) }\end{array}$ & $\begin{array}{c}\text { Molecular Mass } \\
\text { (Calculated) (kDa) }\end{array}$ & $\begin{array}{c}\text { Molecular Mass } \\
\text { (SDS-PAGE) (kDa) }\end{array}$ \\
\hline BSA & - & $0.0 \pm 0.21$ & 66.4 & 65.4 \\
$\mathbf{1 5}$ & 73.7 & $16.6 \pm 0.20$ & 81.8 & 78.8 \\
$\mathbf{1 6}$ & 73.3 & $16.3 \pm 0.10$ & 81.5 & 78.3 \\
$\mathbf{1 7}$ & 72.4 & $16.5 \pm 0.26$ & 81.7 & 78.6 \\
\hline
\end{tabular}

\subsection{Galectin Binding Assays}

Binding properties of human Gal-3 and truncated Gal-3 $\Delta$, lacking N-terminal amino acid residues 1-62, were investigated in an enzyme-linked lectin assay (ELLA) using multivalent BSA neo-glycoproteins 15-17 as ligands. For this purpose, Gal-3 and Gal-3 $\Delta$ were expressed in E. coli Rosetta (DE3) and purified by affinity chromatography as published previously $[50,55,57,58]$. The binding of Gal-3 and Gal-3 $\Delta$ at varying concentrations to immobilized neo-glycoprotein 15-17 was quantified by an anti-His 6 specific antibody. Neo-glycoprotein 18 was utilized as reference [50] due to presented LacNAc type 2 tetrasaccharides (Figure S16, Supporting Information). The corresponding binding curves are depicted in Figure S16 (Supporting Information). For a quantitative comparison, the maximum binding signal $\left(\mathrm{B}_{\max }\right)$ and the galectin concentration for half-maximum binding (apparent $K_{d}$ value) were calculated (Table 4). The binding efficiencies $\left(\mu \mathrm{M}^{-1}\right)$, defined as the ratio of $\mathrm{B}_{\max } / \mathrm{K}_{\mathrm{d}}$, were determined as direct measure for galectin binding characteristics and are illustrated in Figure 3. The $B_{\max }$ values of Gal-3 and Gal-3 $\Delta$ are quite comparable within the measured standard deviation (Table 4). Both Gal-3 and Gal-3 $\Delta$ showed the highest $B_{\max }$ for neo-glycoprotein 17. On the contrary, we observed substantial differences of the apparent $\mathrm{K}_{\mathrm{d}}$ affinity constants, making those the most contributing factors for evaluation of binding efficiencies. 
Table 4. Binding behavior of Gal-3 and Gal-3 $\Delta$ to BSA neo-glycoproteins 15-18.

\begin{tabular}{|c|c|c|c|c|c|c|}
\hline Neo-Glycoprotein & \multicolumn{2}{|c|}{ Galectin Binding Efficiency $\left(\mu \mathbf{M}^{-1}\right)$} & \multicolumn{2}{|c|}{ Maximal Binding Signal $\left(B_{\max }\right)$} & \multicolumn{2}{|c|}{ Apparent $K_{d}$ Value $(\mu M)$} \\
\hline 15 & $0.41 \pm 0.02$ & $1.79 \pm 0.20$ & $1.05 \pm 0.02$ & $1.00 \pm 0.04$ & $2.56 \pm 0.09$ & $0.56 \pm 0.04$ \\
\hline 17 & $0.54 \pm 0.15$ & $0.87 \pm 0.10$ & $1.15 \pm 0.10$ & $1.10 \pm 0.04$ & $2.14 \pm 0.41$ & $1.27 \pm 0.10$ \\
\hline $18 *$ & $2.97 \pm 0.52$ & $3.57 \pm 0.72$ & $1.01 \pm 0.09$ & $1.00 \pm 0.06$ & $0.34 \pm 0.09$ & $0.28 \pm 0.04$ \\
\hline
\end{tabular}

* neo-glycoprotein 18 was prepared as previously published [50]. The structure is depicted in the Supporting Information (Figure S16).

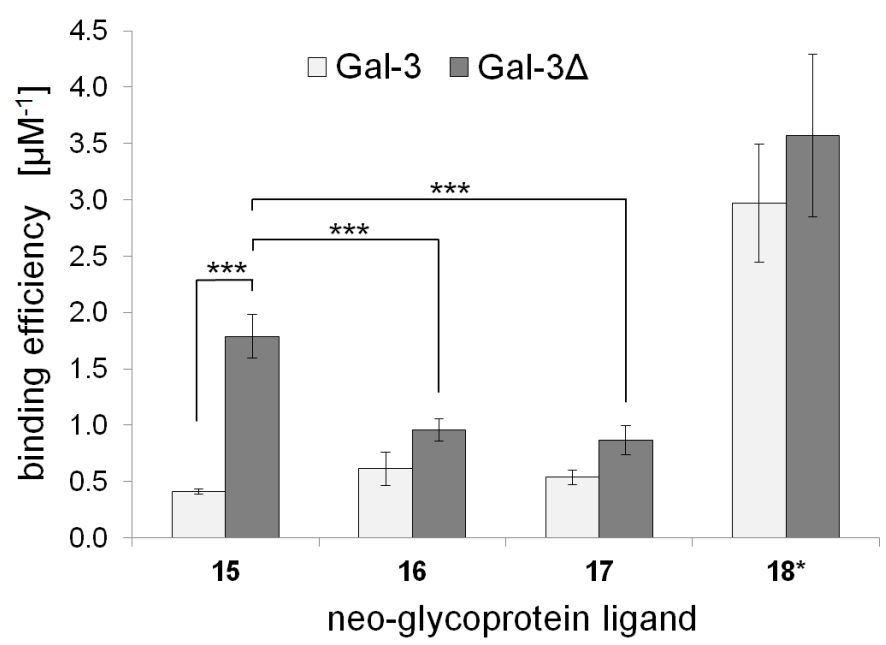

Figure 3. Binding efficiencies of Gal-3 and Gal-3 $\Delta$ for BSA neo-glycoproteins 15-18. Conjugate 18 featured di-LacNAc type 2 tetrasaccharides and was prepared as previously published [50]. The structure is depicted in the Supporting Information (Figure S16).

In general, the binding efficiency of Gal-3 $\Delta$ was consistently increased compared to Gal-3. Furthermore, the binding affinity and efficiency of both Gal-3 and Gal-3 $\Delta$ was highest when using conjugate 18 [50] as a reference due to a multivalent presentation of LacNAc type 2 glycans as well-known galectin ligands. Among the LacNAc type 1 containing conjugates (15-17), di-LacNAc type 1 presenting neo-glycoprotein 15 was the preferred ligand of Gal-3 $\Delta$ (Figure 3). Gal-3 $\Delta$ binding efficiency for conjugate 15 was more than 4-fold elevated compared to those for Gal-3, being statistically significant with $p<0.001$ (Figure 3$)$. In contrast, Gal-3 $\Delta$ binding was significantly $(p<0.001)$ reduced when hybrids of LacNAc type 1 and type 2 are present (neo-glycoproteins 16 and 17), making them to less favored ligands of Gal-3 $\Delta$ in our study. Neo-glycoprotein 18 (di-LacNAc type 2) is, however, the most effective ligand for Gal-3 and Gal-3 $\Delta$ binding. Nevertheless, we demonstrate that neo-glycoprotein 15 is a selective multivalent glycoconjugate for binding of Gal-3 $\Delta$ with the potential to discriminate between Gal-3 and Gal-3 $\Delta$ (Table 4, Figure 3). In contrast, the LacNAc type 1/2 hybrid structures $(\mathbf{1 6}, \mathbf{1 7})$ and di-LacNAc type 2 glycans $(\mathbf{1 8})$ did not depict significant differences in binding of Gal-3 and Gal-3 $\Delta$.

Probably, the carbohydrate recognition domain (CRD) of the Gal-3 $\Delta$ variant may undergo a conformational change as consequence of its $N$-terminal truncation by MMPs. Our results confirm also previous microarray studies suggesting that LacNAc type 1 glycans are less potent ligands of full-length Gal-3 [59]. LacNAc type 1-presenting neo-glycoprotein $\mathbf{1 5}$ may be a promising candidate for the development of anti-cancer vaccines $[60,61]$. 


\section{Materials and Methods}

\subsection{Nucleotide Sugar Synthesis}

The nucleotide sugars UDP-Gal and UDP-GlcNAc were provided by enzymatic synthesis, as described previously [19]. A lyophilization step was performed to adjust higher concentrations in starting donor substrate solutions. Concentrations of nucleotide sugars were determined by capillary electrophoresis (Supporting Information Figure S2) [19].

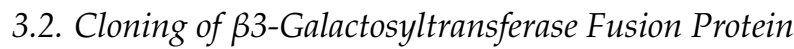

The synthetic gene encoding $\beta 1,3$-galactosyltransferase from Escherichia coli (E. coli) O55:H7 ( $33 \mathrm{GalT})$ [17] with C-terminal fusion of lipase pre-propeptide (pp) from Staphylococcus hyicus was purchased from GeneArt ${ }^{\mathrm{TM}}$ (ThermoFisher Scientific, Darmstadt, Germany). The sequence was codon optimized for recombinant expression in E. coli. The functional expression and purification (via $\mathrm{His}_{6}$-tag) of the $\beta 1,3$-galactosyltransferase from E. coli O55:H7 failed when cloned into vectors pET-15b and pET-22b, respectively [17]. The lipase pre-propeptide from Staphylococcus hyicus [44] was employed as spacer between the enzyme's coding region and the vector (pET-22b) containing C-terminal His $_{6}$-tag, which enabled immobilized metal-ion affinity chromatography. Digestion of both the expression vector (pET22b) and the synthetic gene using NdeI and XhoI according to manufacturer's instructions enabled sticky end ligation by usage of T4 DNA ligase (ThermoFisher Scientific, Darmstadt, Germany). Vector pET22b featured a C-terminal His ${ }_{6}$-tag for affinity chromatography, as well as ampicillin marker for selection. Finally, integrity of $\beta 3 \mathrm{GalTppHis}{ }_{6}$ construct $(\beta 3 \mathrm{GalT})$ was confirmed by sequencing (Sequiserve $\mathrm{GmbH}$, Vaterstetten, Germany). The primer sequences were 5'-TAATACGACTCACTATAGG-3' (forward primer) and 3'-GCTAGTTATTGCTCAGCG-5' (reverse primer). The pelB leader sequence of $\mathrm{pET} 22 \mathrm{~b}$ vector was cut by restriction enzyme. Thereby, putative periplasmic secretion of target protein was prevented.

\subsection{Production of Recombinant Enzymes and Human Galectins}

Heterologous protein expression and subsequent purification was carried out as described previously $[44,46,47,50,55,62]$. The $\beta 3$ GalT fusion protein featuring a C-terminally fused lipase pre-propeptide from Staphylococcus hyicus and $\mathrm{His}_{6}$-tag ( $\beta 3 \mathrm{GalT}$ ) and the $\beta 1,3-N$-acetylglucosaminyltransferases from Helicobacter pylori with an $N$-terminal maltose binding protein ( 33 GlcNAcT) were produced in E.coli BL21 (DE3) (Novagen/Merck, Darmstadt, Germany) [45-47]. Briefly, E. coli BL21 (DE3) cells were grown in 1 L terrific broth (TB) medium (5 L baffled flask, $80 \mathrm{rpm}$ ) at $37^{\circ} \mathrm{C}$ to an optical density $\left(\mathrm{OD}_{600}\right)$ of $0.6-0.8$. After induction with isopropyl- $\beta$-D-thiogalactopyranoside (IPTG, $0.1 \mathrm{mM}$ ), further cultivation was performed at $20^{\circ} \mathrm{C}$ for $22 \mathrm{~h}$. The human $\beta 1$,4-galactosyltransferase-1 fusion protein ( $\beta 4 \mathrm{GalT}$ ) was produced in E. coli Shuffle T7 Express (DE3) (NEB, Frankfurt/Main, Germany) as previously published [44,47]. After $24 \mathrm{~h}$ cell culture, cells were harvested by centrifugation. A $40 \% w / v$ cell suspension was sonicated, centrifuged (13,000 rpm, $5 \mathrm{~min})$, and the supernatant was used for purification. The His ${ }_{6}$-tagged proteins were isolated using a HisTrap ${ }^{\mathrm{TM}}$ HP $5 \mathrm{~mL}$ column (GE Healthcare, Munich, Germany) as recommended by the manufacturer. The elution buffer of $\beta 3$ GalT was supplemented with $0.2 \%(v / v)$ Triton $^{\mathrm{TM}}$ X-100. MBPTrap ${ }^{\mathrm{TM}}$ HP $5 \mathrm{~mL}$ column (GE Healthcare) was applied for purification of MBP-tagged protein $(\beta 3 \mathrm{GlcNAcT})$. The buffer of eluted $\beta 3 \mathrm{GalT}$ was exchanged by dialysis against phosphate buffer (100 $\mathrm{mM} \mathrm{NaH}_{2} \mathrm{PO}_{4}, 500 \mathrm{mM} \mathrm{NaCl}, 5 \mathrm{mM}$ DTT, pH 7.5).

The human galectin fusion constructs $\mathrm{His}_{6}-\mathrm{Gal}-3$ (Gal-3) and the truncated version $\mathrm{His}_{6}-\mathrm{Gal}_{-} 3$ (Gal-3 $\Delta 1-62$, Gal-3 $\Delta$ ) were produced in E. coli Rosetta (DE3) pLysS (Novagen/Merck, Darmstadt, Germany) and purified, as described previously [50,55,57]. Immobilized metal-ion affinity chromatography (IMAC) was carried out via HisTrap ${ }^{\mathrm{TM}} \mathrm{HP} 5 \mathrm{~mL}$ columns as mentioned above. The buffer of eluted galectins was exchanged by dialysis against phosphate buffered saline containing 
ethylenediaminetetraacetic acid (2 mM, EPBS, pH 7.5). Protein concentrations were determined by a Bradford assay (Roti ${ }^{\circledR}$-Quant, Carl Roth, Karlsruhe, Germany) using bovine serum albumin for calibration.

\subsection{Enzyme Activity Assays}

The $\beta 3$ GalT activity was determined in different buffer systems (MES, MOPS, HEPES, Tris and glycine, $100 \mathrm{mM}$ each, $\mathrm{pH} 5.5-10.0)$ containing $25 \mathrm{mM} \mathrm{KCl}, 5 \mathrm{mM}$ of divalent cations $\left(\mathrm{Mg}^{2+}, \mathrm{Mn}^{2+}, \mathrm{Zn}^{2+}\right.$, $\mathrm{Cu}^{2+}, \mathrm{Ca}^{2+}, \mathrm{Co}^{2+}$; applied as chloride salts), $5 \mathrm{mM}$ acceptor $1,6.5 \mathrm{mM} \mathrm{UDP-Gal}$, purified $\beta 3 \mathrm{GalT}(27 \mu \mathrm{g})$, and $3 \mathrm{U}$ alkaline phosphatase (Fast AP, ThermoFisher, Darmstadt, Germany). Additionally, activity was proven under conditions for preparative syntheses using $100 \mathrm{mM}$ HEPES (pH 7.6) containing $25 \mathrm{mM} \mathrm{KCl}, 20 \mathrm{mM} \mathrm{MgCl}_{2}, 10 \mathrm{mM}$ UDP-Gal, $10 \mathrm{mM}$ UDP-GlcNAc, and $5 \mathrm{mM}$ acceptor 1, $10 \mathrm{U}$ alkaline phosphatase (AP, from ThermoFisher), and purified $\beta 3 \mathrm{GalT}(27 \mu \mathrm{g})$. The $\beta 3 \mathrm{GlcNAcT}$ activity was assayed under the same conditions as described for the $\beta 3 \mathrm{GalT}$ with the exception that $5 \mathrm{mM}$ of compound 2 was used as substrate for $\beta 3$ GlcNAcT $(2.5 \mu \mathrm{g})$. The $\beta 4 \mathrm{GalT}$ activity was determined as previously described [44,47] in $100 \mathrm{mM}$ HEPES- $\mathrm{NaOH}$ (pH 7.5) containing $25 \mathrm{mM} \mathrm{KCl}, 6.5 \mathrm{mM} \mathrm{MnCl}$, $6.5 \mathrm{mM}$ UDP-Gal, and acceptor 1 . The total volume of all reactions was adjusted to a final volume of $50 \mu \mathrm{L}$ that was incubated at $30^{\circ} \mathrm{C}$. The reactions were stopped after $0,5,10,15,30,60$, and $120 \mathrm{~min}$ by short heating $\left(95^{\circ} \mathrm{C}\right.$ for $5 \mathrm{~min}$ ) followed by a centrifugation step ( $5 \mathrm{~min}, 13,000 \mathrm{rpm}$ ) to remove denatured protein. The supernatant was diluted 1:5 in water and analyzed by HPLC. The retention time of the compounds was $26.67 \mathrm{~min}$ (1, acceptor) and $21.70 \mathrm{~min}$ (2, product), respectively, as shown in Figure S3 (Supporting Information). Volumetric activity $(\mathrm{U} / \mathrm{mL})$ was deduced from the linear slope area. Specific enzyme activity $(\mathrm{U} / \mathrm{mg})$ was calculated under consideration of protein concentration $(\mathrm{mg} / \mathrm{mL})$. One unit $(1 \mathrm{U})$ was defined as the amount of enzyme that converts one $\mu \mathrm{mol}$ substrate per minute.

\subsection{One-Pot Synthesis of Poly-LacNAc Type 1 Oligomers}

Compound 1 (GlcNAc-linker-tBoc) was synthesized as described previously [46] and used as starting material for glycan synthesis. The one-pot syntheses were carried out on an analytical scale in $100 \mathrm{mM}$ HEPES-NaOH (pH 7.5) supplemented with $25 \mathrm{mM} \mathrm{KCl}$ and $5 \mathrm{mM}$ acceptor 1 . The reactions contained a two-fold excess of UDP-Gal and UDP-GlcNAc (both $10 \mathrm{mM}$ ), $20 \mathrm{mM} \mathrm{MgCl}, 1 \mathrm{mM}$ DTT, and AP (10 U). Varying enzyme activity ratios ( $\beta 3$ GalT / $\beta 3$ GlcNAcT) of 1:5, 1:1, and 5:1 were adjusted, ranging between 2 and $10 \mathrm{mU}$ of appropriate enzymes.

\subsection{Sequential Synthesis of Poly-LacNAc Type 1 Oligomers}

The sequential synthesis was started with acceptor $1(4.3 \mathrm{mg}, 10.1 \mu \mathrm{mol})$, which was consecutively treated alternately with purified $\beta 3 \mathrm{GalT}$ or $\beta 3 \mathrm{GlcNAcT}$ to create a growing oligosaccharide chain of repeating LacNAc type 1 units. The consecutive batches $(2.02 \mathrm{~mL})$ contained $5 \mathrm{mM}$ acceptor substrate, 100 mM HEPES-NaOH (pH 7.5), $25 \mathrm{mM} \mathrm{KCl}, 20 \mathrm{mM} \mathrm{MgCl} 2,10 \mathrm{mM}$ UDP-Gal or $10 \mathrm{mM}$ UDP-GlcNAc, $\mathrm{AP}(10 \mathrm{U})$, and $150 \mathrm{mU} / \mathrm{mL}$ purified enzyme (B3GalT or $\beta 3 \mathrm{GlcNAcT}$ ). After $18 \mathrm{~h}$ (compounds 2-5, 7) or $48 \mathrm{~h}(6,8)$, reactions were stopped by heat and centrifugation as described above. HPLC analysis confirmed the presence of elongated glycans as previously described [47,55]. Removal of denatured enzyme was achieved by ultrafiltration (VivaSpin ${ }^{\circledR} 20$, MWCO $30 \mathrm{kDa}$, Sartorius Stedim Biotech, Goettingen, Germany). Buffer components and UDP sugars were removed by solid-phase extraction using Sep-Pak ${ }^{\circledR} \mathrm{C} 18$ 3cc Vac Cartridges (Waters Corporation, Eschborn, Germany) in order to obtain pure products. Compound 3 was further treated with $\beta 4 \mathrm{GalT}$ as described previously [50] to generate LacNAc type 2 terminated tetrasaccharide $\mathbf{9}$, which was isolated by solid-phase extraction as described above. Compound 11 was obtained by treating compound 10 [50] with $\beta 3 \mathrm{GalT}$ under given reaction conditions in order to add a terminal LacNAc type 1 motif as described above. 


\subsection{HPLC Analysis and Mass Spectrometry}

Activity assays and synthetic reactions were analyzed on a Dionex system using a column packed with MultoKrom 100-5 C18 resin (250 mm $\times 4$ mm, CS-Chromatographie, Langerwehe, Germany). As eluent $15 \%(v / v)$ acetonitrile dissolved in MilliQ water was used at a flow rate of $1 \mathrm{~mL} \cdot \mathrm{min}^{-1}$. LacNAc oligomers could be detected due to presence of the UV-active linker at $254 \mathrm{~nm}$. Mass analysis of oligomers $\mathbf{2 - 1 1}$ was performed by electrospray ionization mass spectrometry (ESI-MS). Pure compounds (0.1-0.2 mM), partly supplemented with $0.5 \mu \mathrm{L}$ ammonium hydroxide, were analyzed on a Multospher $120 \mathrm{RP} 18 \mathrm{HP}-3 \mu$ HPLC column $(60 \mathrm{~mm} \times 2 \mathrm{~mm}$, CS-Chromatographie) at a flow rate of $0.2 \mathrm{~mL} \mathrm{~min}^{-1}$ using MS-grade acetonitrile/water (50:50) as mobile phase. Mass data were collected with a Finnigan Surveyor MSQ Plus (Thermo Scientific, needle voltage, $4 \mathrm{kV}$; temperature, $400{ }^{\circ} \mathrm{C}$; cone voltage, $100 \mathrm{~V}$; negative mode). Mass / charge-ratio $(\mathrm{m} / \mathrm{z}$ ratio) was the fundamental unit for detection of target molecules.

\subsection{Neo-Glycoprotein Synthesis}

Oligomer functionalization with 3,4-diethoxy-3-cyclobutene-1.2-dione (diethyl squarate, $\mathrm{Et}_{2} \mathrm{SQ}$ ) was performed as reported previously [50]. In short, deprotection of compounds $4(2.20 \mu \mathrm{mol}, 2.09 \mathrm{mg})$, $\mathbf{9}(1.99 \mu \mathrm{mol}, 1.89 \mathrm{mg})$ and $\mathbf{1 1}(2.55 \mu \mathrm{mol}, 2.42 \mathrm{mg})$ was performed in $1 \mathrm{M} \mathrm{HCl}$ for $48 \mathrm{~h}$ at $4{ }^{\circ} \mathrm{C}$. After neutralization (Dowex ${ }^{\circledR} 66$ free base, Sigma Aldrich, Steinheim, Germany), a four-fold excess of both the diethyl squarate $\left(\mathrm{Et}_{2} \mathrm{SQ}, 7.96-10.20 \mu \mathrm{mol}, 1.35-1.73 \mathrm{mg}\right)$ and triethylamine $\left(\mathrm{Et}_{3} \mathrm{~N}, 7.96-10.20 \mu \mathrm{mol}\right.$, $0.81-1.03 \mathrm{mg}$ ) was adjusted with regard to deprotected oligosaccharides. Reactions were performed in $50 \%$ aqueous ethanol buffered at pH 7.0 (35 mM HEPES) and analyzed by analytical HPLC as described before [50]. Semi-preparative HPLC (Supporting Information Figure S13-S15) was performed for isolation of pure squarate monoamide esters 12-14 followed by mass spectrometry analysis (Supporting Information Figures MS 11-13). Squarate monoamide esters 12-14 $(0.39 \mu \mathrm{mol})$ were mixed with delipidated BSA (1.16 mg, $1.04 \mu \mathrm{mol}$ lysine residues) in the second coupling reaction using borate buffer (50 $\mathrm{mM} \mathrm{Na}_{2} \mathrm{~B}_{4} \mathrm{O}_{7}, \mathrm{pH}$ 9.0). After seven days, the number of modified lysine residues of neo-glycoproteins 15-17 was quantified by TNBSA assay as described before [50]. After filtration and buffer exchange (deionized water, VivaSpin ${ }^{\circledR}$ 500, Sartorius Stedim Biotech, Goettingen, Germany), neo-glycoproteins $\mathbf{1 5 - 1 7}$ were further analyzed by SDS-PAGE [50].

\subsection{Galectin Binding Assays and Statistical Analysis}

Neo-glycoproteins 15-17 were applied as ligands for Gal-3 and Gal-3 $\Delta$ in an ELLA-type assay. Appropriate amounts of 15-17 $(0.1 \mu \mathrm{M}$ in PBS, $50 \mu \mathrm{L}, 5$ pmol per well) were immobilized overnight in F16 Maxisorp NUNC-Immuno Modules (Thermo Scientific, Roskilde, Denmark). After three washing steps using PBS supplemented with $0.05 \%(v / v)$ Tween 20 (PBST), a solution containing $2 \%(w / v)$ delipidated BSA dissolved in PBS was used to block residual binding sites. A subsequent washing step was performed before Gal-3 and Gal-3 $\Delta$ were added at different concentrations (1-5000 nM, $50 \mu \mathrm{L}$ ) and incubated for $1 \mathrm{~h}$ at room temperature. Removal of non-bound galectin was achieved by three-fold PBST washing. Peroxidase conjugated anti-His 6 -IgG2a from mouse (Roche Diagnostics, Mannheim, Germany) was diluted in PBS (1:4000) and added to each well (50 $\mu \mathrm{L}, 1 \mathrm{~h}$, room temperature). After three additional washing steps (PBST) reaction of IgG-conjugated peroxidase was initiated by 3,3'5,5'-tetramethylbenzidine (TMB) One (Kem-En-Tec, Taastrup, Denmark) substrate solution $(50 \mu \mathrm{L})$ and stopped by $3 \mathrm{M} \mathrm{HCl}(50 \mu \mathrm{L})$. Galectin binding signal was quantified by measuring optical density at $450 \mathrm{~nm}$ using Spectra Max Plus (Molecular Devices, Biberach, Germany) plate reader. SigmaPlot software was utilized for further analysis of half-maximal binding (apparent $K_{d}$ ) and maximum binding signal $\left(B_{\max }\right)$, outlined in Equations (1) and (2). Data was statistically analyzed using a $t$-test with a confidence interval with $p<0.001(n=3)$.

$$
Y=\frac{B_{\max } \cdot X}{k_{d}+X}
$$


The determination of half-maximal $\left(K_{d}\right)$ and maximal binding $\left(B_{\max }\right)$ signals were calculated by using SigmaPlot software (SigmaPlot 10, Systat Software GmbH, Erkrath, Germany); $Y$, binding signal; $X$, galectin concentration $(\mu \mathrm{M})$.

$$
\begin{aligned}
& \text { binding efficiency }=\frac{B_{\max }}{k_{d}}(A) \\
& \sigma_{\text {binding efficiency }}=\left(\frac{\sigma_{B \max }}{B_{\max }}+\frac{\sigma_{k_{d}}}{k_{d}}\right) \cdot \text { bindingefficiency }(B)
\end{aligned}
$$

where $(A)$ is the determination of binding efficiency and the corresponding standard deviation $(\sigma, B)$ is the quotient of the maximal binding signal $\left(B_{\max }\right)$ and the half-maximal binding signal.

\section{Conclusions}

We present here, for the first time, an efficient synthesis of LacNAc type 1 oligomers by the sequential use of two recombinant Leloir-glycosyltransferases. Tetrasaccharide glycans containing either di-LacNAc type 1 or LacNAc type 1/type 2 hybrid structures were utilized for the synthesis of multivalent BSA neo-glycoproteins. Galectin binding assays reveal the di-LacNAc type 1 glycan motif as highly selective for binding of Gal-3 $\Delta$, the cancer related $N$-terminally truncated version of full-length Gal-3. LacNAc type 1 presenting neo-glycoproteins may, thus, be useful candidates for tracing Gal-3 $\Delta$ during tumor progression.

Supplementary Materials: The following are available online: Figure S1. Characterization of novel $\beta 3 \mathrm{GalT}$ construct; Figure S2. Quantification of nucleotide sugars; Figures S3-S11. HPLC chromatograms for the synthesis of compounds 2-10; Figure S12. Specific $\beta 1$,3-galactosidase digestion of LacNAc type 1 structure; Figures S13-S15. Isolation of squarate monoamide esters 11-13; Table S1. Mass spectrometry analysis of compounds 11-13; b Graphs for galectin binding to neo-glycoproteins 15-17; Figures MS1-MS13. Mass spectrometry spectra for all synthesized compounds.

Acknowledgments: The authors thank Vladimír Křen and co-workers (Academy of Science of the Czech Republic) for providing GlcNAc-linker-tBoc. The authors gratefully acknowledge financial support by the Federal Ministry for Education and Research (BMBF) through the projects "The Golgi Glycan Factory" (AZ: 031 A162) and "The Golgi Glycan Factory 2.0" (AZ: 031A557A) as part of the BMBF program Biotechnology 2020+-Basic Technologies and by the German Research Foundation (DFG, project EL 135/12-1).

Author Contributions: Thomas Fischöder (T.F.), Dominic Laaf (D.L.), and Lothar Elling (L.E.) designed this study; Thomas Fischöder (T.F.), Dominic Laaf (D.L.), and Carina Dey (C.D.) planned the experiments; Thomas Fischöder (T.F.), Dominic Laaf (D.L.), and Carina Dey (C.D.) performed the syntheses; Dominic Laaf (D.L.) performed the neo-glycoprotein analyses and galectin binding assays; and Thomas Fischöder (T.F.), Dominic Laaf (D.L.), Carina Dey (C.D.), and Lothar Elling (L.E.) wrote the paper.

Conflicts of Interest: The authors declare no conflict of interest.

\section{References}

1. Holgersson, J.; Löfling, J. Glycosyltransferases involved in type 1 chain and lewis antigen biosynthesis exhibit glycan and core chain specificity. Glycobiology 2006, 16, 584-593. [CrossRef] [PubMed]

2. Kerr, C.L.; Hanna, W.F.; Shaper, J.H.; Wright, W.W. Lewis X-containing glycans are specific and potent competitive inhibitors of the binding of zp3 to complementary sites on capacitated, acrosome-intact mouse sperm1. Biol. Reprod. 2004, 71, 770-777. [CrossRef] [PubMed]

3. Mitchell, E.; Houles, C.; Sudakevitz, D.; Wimmerova, M.; Gautier, C.; Perez, S.; Wu, A.M.; Gilboa-Garber, N.; Imberty, A. Structural basis for oligosaccharide-mediated adhesion of pseudomonas aeruginosa in the lungs of cystic fibrosis patients. Nat. Struct. Mol. Biol. 2002, 9, 918-921. [CrossRef] [PubMed]

4. Bode, L. Human milk oligosaccharides: Every baby needs a sugar mama. Glycobiology 2012, 22, 1147-1162. [CrossRef] [PubMed]

5. German, J.B.; Freeman, S.L.; Lebrilla, C.B.; Mills, D.A. Human milk oligosaccharides: Evolution, structures and bioselectivity as substrates for intestinal bacteria. Nestle Nutr. Inst. Workshop Ser. Pediatr. Program 2008, 62, 205-218.

6. Petschacher, B.; Nidetzky, B. Biotechnological production of fucosylated human milk oligosaccharides: Prokaryotic fucosyltransferases and their use in biocatalytic cascades or whole cell conversion systems. J. Biotechnol. 2016, 235, 61-83. [CrossRef] [PubMed] 
7. Thurin, M.; Kieber-Emmons, T. Sa-lea and tumor metastasis: The old prediction and recent findings. Hybrid. Hybridomics 2002, 21, 111-116. [CrossRef] [PubMed]

8. Fan, Y.Y.; Yu, S.Y.; Ito, H.; Kameyama, A.; Sato, T.; Lin, C.H.; Yu, L.C.; Narimatsu, H.; Khoo, K.H. Identification of further elongation and branching of dimeric type 1 chain on lactosylceramides from colonic adenocarcinoma by tandem mass spectrometry sequencing analyses. J. Biol. Chem. 2008, 283, 16455-16468. [CrossRef] [PubMed]

9. Stroud, M.R.; Levery, S.B.; Nudelman, E.D.; Salyan, M.E.; Towell, J.A.; Roberts, C.E.; Watanabe, M.; Hakomori, S. Extended type 1 chain glycosphingolipids: Dimeric lea (III4V4Fuc2Lc6) as human tumor-associated antigen. J. Biol. Chem. 1991, 266, 8439-8446. [PubMed]

10. Falk, K.-E.; Karlsson, K.-A.; Larson, G.; Thurin, J.; Blaszczyk, M.; Steplewski, Z.; Koprowski, H. Mass spectrometry of a human tumor glycolipid antigen being defined by mouse monoclonal antibody NS-19-9. Biochem. Biophys. Res. Commun. 1983, 110, 383-391. [CrossRef]

11. Gong, E.; Hirohashi, S.; Shimosato, Y.; Watanabe, M.; Ino, Y.; Teshima, S.; Kodaira, S. Expression of carbohydrate antigen 19-9 and stage-specific embryonic antigen 1 in nontumorous and tumorous epithelia of the human colon and rectum. J. Natl. Cancer Inst. 1985, 75, 447-454. [PubMed]

12. Magnani, J.L.; Nilsson, B.; Brockhaus, M.; Zopf, D.; Steplewski, Z.; Koprowski, H.; Ginsburg, V. A monoclonal antibody-defined antigen associated with gastrointestinal cancer is a ganglioside containing sialylated lacto-n-fucopentaose ii. J. Biol. Chem. 1982, 257, 14365-14369. [PubMed]

13. Ugorski, M.; Laskowska, A. Sialyl lewis(a): A tumor-associated carbohydrate antigen involved in adhesion and metastatic potential of cancer cells. Acta Biochim. Pol. 2002, 49, 303-311. [PubMed]

14. Pettijohn, D.E.; Pfenninger, O.; Brown, J.; Duke, R.; Olsson, L. Tumorigenic human squamous lung cancer cells have defined cell surface carbohydrates that are absent from nontumorigenic cells. Proc. Natl. Acad. Sci. USA 1988, 85, 802-806. [CrossRef] [PubMed]

15. Ugorski, M.; Påhlsson, P.; Dus, D.; Nilsson, B.; Skouv, J.; Radzikowski, C. The sialosyl lewisa ganglioside is present in tumorigenic human urothelial cell lines. Int. J. Cancer 1990, 45, 1204-1209. [CrossRef] [PubMed]

16. Henze, M.; Schmidtke, S.; Hoffmann, N.; Steffens, H.; Pietruszka, J.; Elling, L. Combination of glycosyltransferases and a glycosynthase in sequential and one-pot reactions for the synthesis of type 1 and type $2 \mathrm{~N}$-acetyllactosamine oligomers. ChemCatChem 2015, 7, 3131-3139. [CrossRef]

17. Liu, X.-W.; Xia, C.; Li, L.; Guan, W.-Y.; Pettit, N.; Zhang, H.-C.; Chen, M.; Wang, P.G. Characterization and synthetic application of a novel $\beta 1,3$-galactosyltransferase from escherichia coli O55:H7. Bioorg. Med. Chem. 2009, 17, 4910-4915. [CrossRef] [PubMed]

18. Chen, Y.; Thon, V.; Li, Y.; Yu, H.; Ding, L.; Lau, K.; Qu, J.; Hie, L.; Chen, X. One-pot three-enzyme synthesis of udp-glcnac derivatives. Chem. Commun. 2011, 47, 10815-10817. [CrossRef] [PubMed]

19. Wahl, C.; Hirtz, D.; Elling, L. Multiplexed capillary electrophoresis as analytical tool for fast optimization of multi-enzyme cascade reactions - synthesis of nucleotide sugars. Biotechnol. J. 2016, 11, 1298-1308. [CrossRef] [PubMed]

20. Barondes, S.H.; Cooper, D.N.; Gitt, M.A.; Leffler, H. Galectins. Structure and function of a large family of animal lectins. J. Biol. Chem. 1994, 269, 20807-20810. [PubMed]

21. Fred Brewer, C. Binding and cross-linking properties of galectins. Biochim. Biophys. Acta Gen. Subj. 2002, 1572, 255-262. [CrossRef]

22. Leffler, H.; Carlsson, S.; Hedlund, M.; Qian, Y.; Poirier, F. Introduction to galectins. Glycoconj. J. 2004, 19, 433-440. [CrossRef] [PubMed]

23. Klyosov, A.A.; Witczak, Z.J.; Platt, D. Galectins and their functions in plain language. In Galectins; John Wiley \& Sons, Inc.: Hoboken, NJ, USA, 2008; pp. 9-31.

24. Gabius, H.-J.; Siebert, H.-C.; André, S.; Jiménez-Barbero, J.; Rüdiger, H. Chemical biology of the sugar code. ChemBioChem 2004, 5, 740-764. [CrossRef] [PubMed]

25. Gabius, H.-J. Glycans: Bioactive signals decoded by lectins. Biochem. Soc. Trans. 2008, 36, 1491-1496. [CrossRef] [PubMed]

26. Compagno, D.; Gentilini, L.D.; Jaworski, F.M.; Perez, I.G.; Contrufo, G.; Laderach, D.J. Glycans and galectins in prostate cancer biology, angiogenesis and metastasis. Glycobiology 2014, 24, 899-906. [CrossRef] [PubMed]

27. D’Haene, N.; Maris, C.; Rorive, S.; Decaestecker, C.; Le Mercier, M.; Salmon, I. Galectins and neovascularization in central nervous system tumors. Glycobiology 2014, 24, 892-898. [CrossRef] [PubMed]

28. Griffioen, A.W.; Thijssen, V.L. Galectins in tumor angiogenesis. Ann. Transl. Med. 2014, 2, 90. [PubMed] 
29. Le Mercier, M.; Fortin, S.; Mathieu, V.; Kiss, R.; Lefranc, F. Galectins and gliomas. Brain Pathol. 2010, 20, 17-27. [CrossRef] [PubMed]

30. Liu, F.T.; Rabinovich, G.A. Galectins as modulators of tumour progression. Nat. Rev. Cancer 2005, 5, $29-41$. [CrossRef] [PubMed]

31. Nakahara, S.; Oka, N.; Raz, A. On the role of galectin-3 in cancer apoptosis. Apoptosis 2005, 10, $267-275$. [CrossRef] [PubMed]

32. Rabinovich, G.A.; van Kooyk, Y.; Cobb, B.A. Glycobiology of immune responses. Ann. N. Y. Acad. Sci. 2012, 1253, 1-15. [CrossRef] [PubMed]

33. Markowska, A.I.; Liu, F.-T.; Panjwani, N. Galectin-3 is an important mediator of vegf- and bfgf-mediated angiogenic response. J. Exp. Med. 2010, 207, 1981-1993. [CrossRef] [PubMed]

34. Elola, M.T.; Blidner, A.G.; Ferragut, F.; Bracalente, C.; Rabinovich, G.A. Assembly, organization and regulation of cell-surface receptors by lectin-glycan complexes. Biochem. J. 2015, 469, 1-16. [CrossRef] [PubMed]

35. Dumic, J.; Dabelic, S.; Flogel, M. Galectin-3: An open-ended story. Biochim. Biophys. Acta 2006, 1760, 616-635. [CrossRef] [PubMed]

36. Pugliese, G.; Iacobini, C.; Pesce, C.M.; Menini, S. Galectin-3: An emerging all-out player in metabolic disorders and their complications. Glycobiology 2015, 25, 136-150. [CrossRef] [PubMed]

37. Guevremont, M.; Martel-Pelletier, J.; Boileau, C.; Liu, F.T.; Richard, M.; Fernandes, J.C.; Pelletier, J.P.; Reboul, P. Galectin-3 surface expression on human adult chondrocytes: A potential substrate for collagenase-3. Ann. Rheum. Dis. 2004, 63, 636-643. [CrossRef] [PubMed]

38. Ochieng, J.; Green, B.; Evans, S.; James, O.; Warfield, P. Modulation of the biological functions of galectin-3 by matrix metalloproteinases. Biochim. Biophys. Acta Gen. Subj. 1998, 1379, 97-106. [CrossRef]

39. Nangia-Makker, P.; Raz, T.; Tait, L.; Hogan, V.; Fridman, R.; Raz, A. Galectin-3 cleavage: A novel surrogate marker for matrix metalloproteinase activity in growing breast cancers. Cancer Res. 2007, 67, 11760-11768. [CrossRef] [PubMed]

40. John, C.M.; Leffler, H.; Kahl-Knutsson, B.; Svensson, I.; Jarvis, G.A. Truncated galectin-3 inhibits tumor growth and metastasis in orthotopic nude mouse model of human breast cancer. Clin. Cancer Res. 2003, 9 , 2374-2383. [PubMed]

41. Mirandola, L.; Nguyen, D.D.; Rahman, R.L.; Grizzi, F.; Yuefei, Y.; Figueroa, J.A.; Jenkins, M.R.; Cobos, E.; Chiriva-Internati, M. Anti-galectin-3 therapy: A new chance for multiple myeloma and ovarian cancer? Int. Rev. Immunol. 2014, 33, 417-427. [CrossRef] [PubMed]

42. Mirandola, L.; Yu, Y.; Chui, K.; Jenkins, M.R.; Cobos, E.; John, C.M.; Chiriva-Internati, M. Galectin-3c inhibits tumor growth and increases the anticancer activity of bortezomib in a murine model of human multiple myeloma. PLoS ONE 2011, 6, e21811. [CrossRef] [PubMed]

43. Engels, L.; Elling, L. Wbgl: A novel bacterial alpha1,2-fucosyltransferase for the synthesis of $2^{\prime}$-fucosyllactose. Glycobiology 2014, 24, 170-178. [CrossRef] [PubMed]

44. Sauerzapfe, B.; Namdjou, D.J.; Schumacher, T.; Linden, N.; Křenek, K.; Křen, V.; Elling, L. Characterization of recombinant fusion constructs of human $\beta 1$,4-galactosyltransferase 1 and the lipase pre-propeptide from staphylococcus hyicus. J. Mol. Catal. B Enzym. 2008, 50, 128-140. [CrossRef]

45. Logan, S.M.; Altman, E.; Mykytczuk, O.; Brisson, J.-R.; Chandan, V.; Michael, F.S.; Masson, A.; Leclerc, S.; Hiratsuka, K.; Smirnova, N.; et al. Novel biosynthetic functions of lipopolysaccharide rfaj homologs from helicobacter pylori. Glycobiology 2005, 15, 721-733. [CrossRef] [PubMed]

46. Sauerzapfe, B.; Křenek, K.; Schmiedel, J.; Wakarchuk, W.W.; Pelantová, H.; Křen, V.; Elling, L. Chemo-enzymatic synthesis of poly- $N$-acetyllactosamine (poly-LacNAc) structures and their characterization for cgl2-galectin-mediated binding of ecm glycoproteins to biomaterial surfaces. Glycoconj. J. 2009, 26, 141-159. [CrossRef] [PubMed]

47. Rech, C.; Rosencrantz, R.R.; Křenek, K.; Pelantová, H.; Bojarová, P.; Römer, C.E.; Hanisch, F.-G.; Křen, V.; Elling, L. Combinatorial one-pot synthesis of poly- $N$-acetyllactosamine oligosaccharides with leloir-glycosyltransferases. Adv. Synth. Catal. 2011, 353, 2492-2500. [CrossRef]

48. Henze, M.; You, D.-J.; Kamerke, C.; Hoffmann, N.; Angkawidjaja, C.; Ernst, S.; Pietruszka, J.; Kanaya, S.; Elling, L. Rational design of a glycosynthase by the crystal structure of $\beta$-galactosidase from bacillus circulans (Bgac) and its use for the synthesis of $N$-acetyllactosamine type 1 glycan structures. J. Biotechnol. 2014, 191, 78-85. [CrossRef] [PubMed] 
49. Kamerke, C.; Pattky, M.; Huhn, C.; Elling, L. Synthesis of nucleotide-activated disaccharides with recombinant $\beta 3$-galactosidase c from bacillus circulans. J. Mol. Catal. B Enzym. 2013, 89, 73-81. [CrossRef]

50. Böcker, S.; Laaf, D.; Elling, L. Galectin binding to neo-glycoproteins: Lacdinac conjugated bsa as ligand for human galectin-3. Biomolecules 2015, 5, 1671-1696. [CrossRef] [PubMed]

51. Lundquist, J.J.; Toone, E.J. The cluster glycoside effect. Chem. Rev. 2002, 102, 555-578. [CrossRef] [PubMed]

52. Pieters, R.J. Maximising multivalency effects in protein-carbohydrate interactions. Org. Biomol. Chem. 2009, 7, 2013-2025. [CrossRef] [PubMed]

53. Pieters, R.J.; Arnusch, C.J.; Breukink, E. Membrane permeabilization by multivalent anti-microbial peptides. Protein Pept. Lett. 2009, 16, 736-742. [CrossRef] [PubMed]

54. Hou, S.J.; Saksena, R.; Kovac, P. Preparation of glycoconjugates by dialkyl squarate chemistry revisited. Carbohydr. Res. 2008, 343, 196-210. [CrossRef] [PubMed]

55. Laaf, D.; Bojarová, P.; Mikulová, B.; Pelantová, H.; Křen, V.; Elling, L. Two-step enzymatic synthesis of $\beta$-D-N-acetylgalactosamine-( $1 \rightarrow 4)$-D- $N$-acetylglucosamine (LacdiNAc) chitooligomers for deciphering galectin binding behavior. Adv. Synth. Catal. 2017, 359, 2101-2108. [CrossRef]

56. Xu, P.; Kelly, M.; Vann, W.F.; Qadri, F.; Ryan, E.T.; Kovac, P. Conjugate vaccines from bacterial antigens by squaric acid chemistry: A closer look. ChemBioChem 2017, 18, 799-815. [CrossRef] [PubMed]

57. Böcker, S.; Elling, L. Binding characteristics of galectin-3 fusion proteins. Glycobiology 2017, 27, 457-468. [CrossRef] [PubMed]

58. Kupper, C.E.; Bocker, S.; Liu, H.; Adamzyk, C.; van de Kamp, J.; Recker, T.; Lethaus, B.; Jahnen-Dechent, W.; Neuss, S.; Muller-Newen, G.; et al. Fluorescent snap-tag galectin fusion proteins as novel tools in glycobiology. Curr. Pharm. Des. 2013, 19, 5457-5467. [CrossRef] [PubMed]

59. Stowell, S.R.; Arthur, C.M.; Mehta, P.; Slanina, K.A.; Blixt, O.; Leffler, H.; Smith, D.F.; Cummings, R.D. Galectin-1, -2 and -3 exhibit differential recognition of sialylated glycans and blood group antigens. J. Biol. Chem. 2008, 283, 10109-10123. [CrossRef] [PubMed]

60. Choo, M.; Tan, H.L.; Ding, V.; Castangia, R.; Belgacem, O.; Liau, B.; Hartley-Tassell, L.; Haslam, S.M.; Dell, A.; Choo, A. Characterization of $\mathrm{h}$ type 1 and type $1 \mathrm{~N}$-acetyllactosamine glycan epitopes on ovarian cancer specifically recognized by the anti-glycan monoclonal antibody mab-a4. J. Biol. Chem. 2017, 292, 6163-6176. [CrossRef] [PubMed]

61. Liu, J.K.H. Anti-cancer vaccines-A one-hit wonder? Yale J. Biol. Med. 2014, 87, 481-489. [PubMed]

62. Šimonová, A.; Kupper, C.E.; Böcker, S.; Müller, A.; Hofbauerová, K.; Pelantová, H.; Elling, L.; Křen, V.; Bojarová, P. Chemo-enzymatic synthesis of LacdiNAc dimers of varying length as novel galectin ligands. J. Mol. Catal. B Enzym. 2014, 101, 47-55. [CrossRef]

Sample Availability: Samples of the LacNAc type 1 containing compounds are available from the authors.

(C) 2017 by the authors. Licensee MDPI, Basel, Switzerland. This article is an open access article distributed under the terms and conditions of the Creative Commons Attribution (CC BY) license (http:/ / creativecommons.org/licenses/by/4.0/). 